\title{
"Take a Knee" Protests in Professional Sports: An Empirical Study about the Influence on Customer Loyalty to Nike in Germany
}

http://doi.org/10.21272/bel.4(1).92-105.2020

Carsten Giebe, ORCID: https://orcid.org/0000-0003-2335-4808

PhD Candidate, Faculty of Economic Science, Kaposvár University, Hungary

Lana Löffler, ORCID: https://orcid.org/0000-0001-7196-629X

PhD Candidate, Faculty of Economic Science, Kaposvár University, Hungary

Sandra Schneider, ORCID: https://orcid.org/0000-0002-6021-2406

PhD Candidate, Faculty of Economic Science, Kaposvár University, Hungary

\begin{abstract}
The article deals with the research of opportunities and prospects to use "Take a knee" protest in professional sports for Nike marketing purposes in terms of influencing customer loyalty to that brand. The action "Take a knee" became widely known in 2016, when the coloured quarterback of the San Francisco 49ers, Colin Kaepernick, knelt in protest while singing the national anthem of the United States of America before several games to denounce police violence against blacks and coloured people. In 2017 the European community for professional sports firstly supported that action, when Hertha BSC's Bundesliga team went down on their knees before the kick-off of a Bundesliga game to demonstrate for diversity, tolerance and responsibility. Since Hertha BSC is equipped with the sporting goods of Nike manufacturer, the article suggested and tested the hypothesis that "Take a knee" could have an impact on customer loyalty growth to the Nike brand. The systematization of the relevant literature sources and approaches to study the demand for sports goods indicates the lack of comprehensive research on the analysis regarding the impact of the atypical advertising measures on consumer behaviour. Based on the systematization of literary sources, the article identifies the controversy of marketing activities with people who engage in politics. Furthermore, the article defines the moral role of individual athletes or teams of different sports using the example of American football and football (also known as soccer). The methodological basis of the study was analytical and comparative methods, methods of analysis, synthesis, and logical generalization. The paper presents the results of an empirical analysis based on a survey of potential customers of sporting goods in Germany in early 2020 with a sample size of 135 respondents. The authors substantiate the importance of continuous and systematic work by the advertising companies aimed at attracting famous people who are politically engaged to advertising companies as a guarantee of increasing customer loyalty. The results of the study can be useful for both business and advertising companies in terms of the choice of marketing communication tools between manufacturer and customer.
\end{abstract}

Keywords: advertising, business ethics, competitiveness, customer loyalty, marketing, Nike, sport and politics, Take a Knee.

JEL Classifications: M14, M31, M37.

This work is licensed under a Creative Commons Attribution 4.0 International License

Cite as: Giebe, C., Löffler, L., Schneider, S. (2020). "Take a knee” Protests in Professional Sports: An Empirical Study about the Influence on Customer Loyalty to Nike in Germany. Business Ethics and Leadership, 4(1), 92-105. http://doi.org/10.21272/bel.4(1).92-105.2020.

(C) The Authors, 2020. This article is published with open access at Sumy State University.

\section{Introduction}

The US American football professional Colin Kaepernick began to sit during the national anthem of a game of the National Football League (NFL) in protest 2016. In other games, the coloured quarterback of the San Francisco 49ers knelt down in protest while singing the national anthem to denounce police violence against blacks and coloured people. A silent protest to show support for coloured people who are oppressed in the United States and to take a stand against police brutality. It's an attempt to use his voice and position as an 
NFL player to make a difference for the people who are suffering. He said he would not stand up to show pride in a flag for a country that oppresses blacks and coloured people. He went on to say that this was bigger to him than (American) football and it would be selfish on his part to look away. He added that there are corpses in the streets and people who are given paid holidays and get away with murder (Lindholm, 2017; Agosto et al., 2019). After his contract was not renewed in San Francisco, no team from the NFL signed him, despite his good performances before. This for reasons that are presumably related to his "Take a knee" activities. Instead, interested teams in his position ultimately signed players with worse performance. In October 2017 Colin Kaepernick filed a lawsuit against the NFL. He referred to the collective agreement between the players' union and the NFL and sued for lost wages and lack of income from advertising contracts. In his last season with the 49ers, Kaepernick had received 14.3 million USD in salary, plus several million from sponsors (Schmieder, 2019).

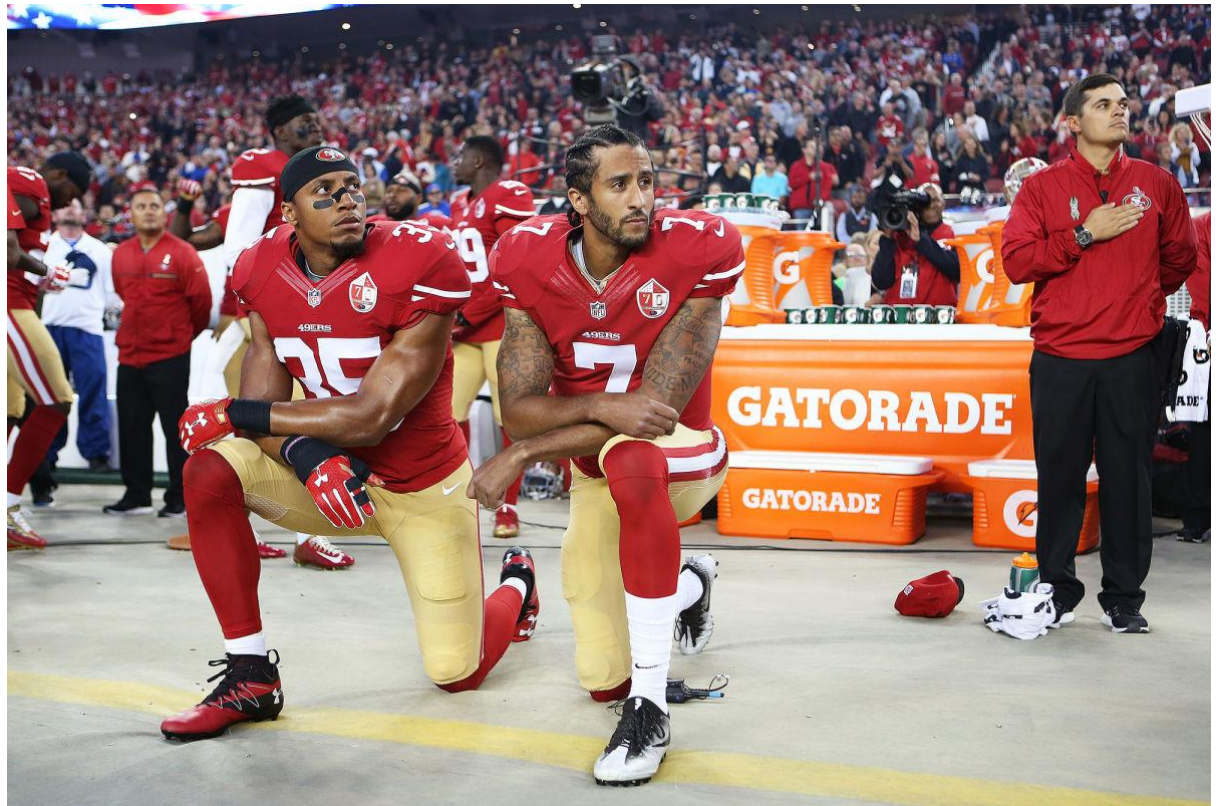

Figure 1. An example of various "Take a knee" activities of Colin Kaepernick in 2016

Source: https://www.newyorker.com/wp-content/uploads/2016/09/Toobin-Kaepernick-Landmark-Supreme-Court-Case-1200.jpg

Before the kick-off of Hertha BSC's Bundesliga match against FC Schalke 04 on 14 October 2017, the entire staff of the Berlin club was on their knees. This makes the football club, which plays in the Bundesliga, the first European club to raise a protest based on Kaepernick. The association justified this with the words "Hertha BSC stands for diversity, tolerance and responsibility! For a Berlin that will remain open to the world in the future!" (Sohn, 2017). The New York Times, ABC News, Chicago Tribune, USA Today and ESPN reported on the kneeling in Berlin in the USA (The New York Times, 2017).

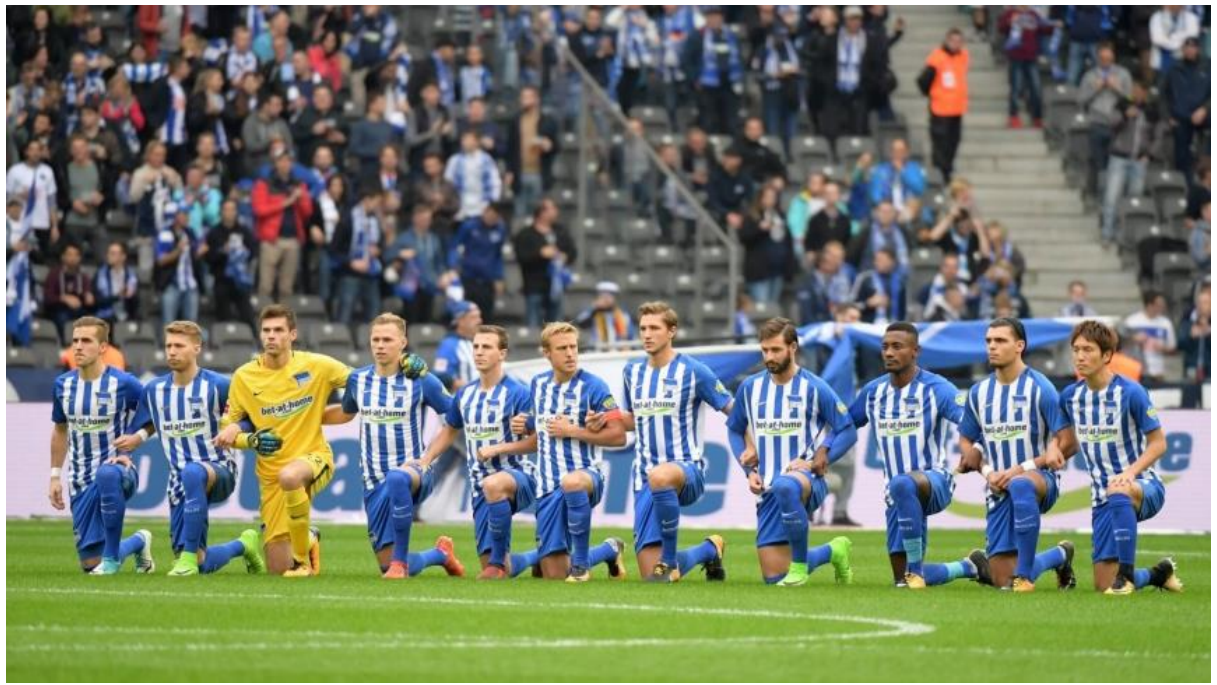

Figure 2. The "Take a knee" protest of Hertha BSC from October 2017

Source: https://www.germanpulse.com/wp-content/uploads/2017/10/Hertha-BSC-TakeAKnee-862x485.jpeg 
In a two-minute video, which was first shown in full length in September 2018, Colin Kaepernick promotes Nike. On the 30th anniversary of the "Just do it" campaign, it celebrates athletes who have overcome obstacles. For example, minorities, people with disabilities, a female Muslim boxer, a professional Football (also known as Soccer) Player who grew up in a refugee camp. However, the spot advertises Kaepernick centrally (Becker, 2018).

American President Donald Trump has stirred up his supporters against Kaepernick and the other protesters (Thiel et al., 2016). On the one hand, thousands of people in the USA boycotted Nike and its products because Kaepernick is the advertising face. His actions made many angry, they took the campaign as an insult to, for example, soldiers. Many have criticized advertising on social networks. Some filmed themselves destroying Nike products and claimed they were boycotting the company. President Trump, who was very critical of the kneeling players during the anthem, questioned the company's decision (Hibbitts, 2018; Martinez, 2018). On the other hand, the publication of the Nike advertising campaign with Colin Kaepernick as a symbolic figure was very well received by many coloured people. Many people endorsed the campaign to draw attention to continuing oppressed minorities in social distress (Hibbitts, 2018; Zannell, 2018). Even former President Barack Obama, the predecessor of U.S. President Trump, commented on this in a televised town hall meeting. He said that part of what makes this country special is that it respects the right of people to have a different opinion (Martin \& McHendry Jr, 2016).

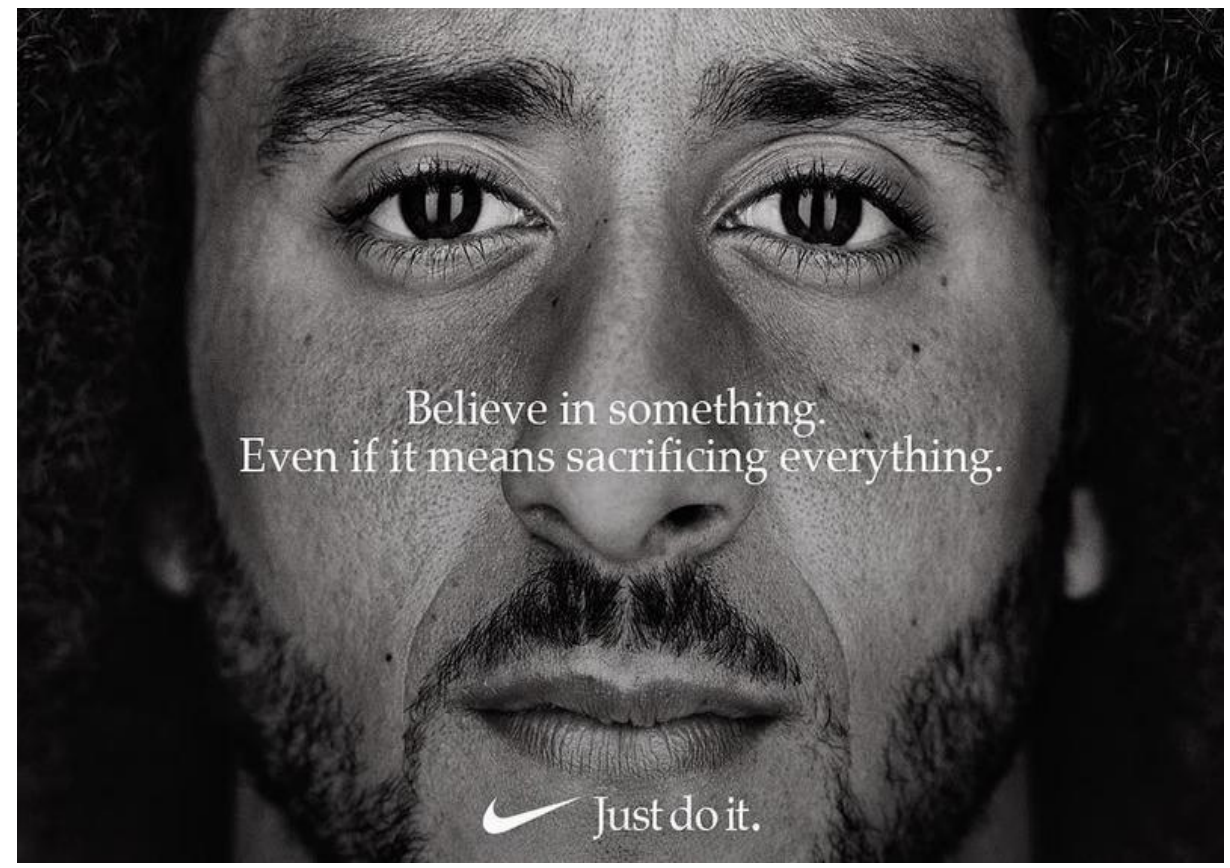

Figure 3. The campaign of Nike with Colin Kaepernick from September 2018

Source: https://image-cdn.hypb.st/https\%3A\%2F\%2Fhypebeast.com\%2Fimage\%2F2018\%2F09\%2Fcolin-kaepernick- nike-just-doit-campaign-1.jpg?q=75\&w=800\&cbr=1\&fit=max

The discussion on racism is more topical than ever in the USA. Zannell sees the present as the rise of ethnonational populism and the subsequent anti-black racism. Under the current government of Donald Trump, we are witnessing discussions that have shown little for the constitution, constitutional rights and inferior communities (Zannell, 2018). In Europe, too, the subject of open racism is unfortunately currently being given a stage. In the match of the national cup competition on 04.02.2020, the player Jordan Torunarigha of Hertha BSC was apparently repeatedly subjected to racist insults by individual members of the home crowd. Interestingly, as in the "Take a knee" campaign in October 2017, the opponent of Hertha BSC was again FC Schalke 04, and the Control Committee of the German Football Association has initiated investigations (Tagesanzeiger, 2020).

\section{Literature Review}

The challenge was to research and bundle different facts when researching for this article. For this purpose, the terms Nike, Colin Kaepernick, Take a knee, Hertha BSC, as well as sport and politics, were first searched 
in various scientific databases. The focus was on scientific peer-reviewed Journal articles in order to give this paper a scientific value. This category includes Agosto et al., 2019; Coombs et al., 2019; Kane et al., 2017, Martin, 2018 and Thiel et.al, 2016. The facts concerning, for example, the Hertha BSC case in connection with their "Take a knee" activity were researched from online pages of daily newspapers. The daily newspaper 'The New York Times' is listed as a representative of this. In addition, the aim was to find out measurable monetary indicators about the Nike company. These were used by the website www.statista.de. From the authors' point of view, valuable content from each category was researched and enriched with their own impulses.

\section{Research question and background}

To what extent do the "Take a knee" activities of American football player Colin Kaepernick (USA) and the Bundesliga football team of Hertha BSC (Germany) have a positive influence on the buying behaviour of Nike products and influence customer loyalty?

We analyze the following statements:

1. From a customer perspective in Germany, "Take a knee" activities ensure greater customer loyalty to Nike.

2. From a customer perspective in Germany, "Take a knee" activities have a positive impact on the Nike brand.

3. From the customer's point of view in Germany, "Take a knee" activities are used by Nike specifically for marketing purposes.

4. From the customer's point of view in Germany, "Take a knee" activities are used by Nike specifically to increase the sales of product numbers of Nike products.

5. From the customer's point of view in Germany, "Take a knee" activities are used by the company Nike specifically to increase sales turnovers of its own products.

6. The age of potential customers is not important for customer retention.

\section{Methods and Hypotheses}

In order to answer the research question, a survey was initiated. This survey was conducted online at www.surveymonkey.de. The premise was a simple and quick answer. The survey period was from 25.01.2020 to 15.02.2020. The assumption is that the respondents are potential customers of sporting goods manufacturers (e.g. Nike). A total of 135 potential customers took part in the survey. We decided on a four-level Likert scale because we did not want to allow, for example, any "abstentions" or "tendency towards the middle". Statistical hypotheses, the significance of which has been tested, are used to examine the six statements above.

The original text of the survey was

The US-American Nike Group is the largest sports goods manufacturer in the world. The reason for these enormous success rates is both brand awareness and successful marketing. To what extent do the "Take a knee" activities of ex-football player Colin Kaepernick (https://www.youtube.com/watch?v=rYFBwavavWc) and the Bundesliga football team of Hertha BSC (https://www.youtube.com/watch?v=P9h3yjAGEyI) influence the buying behaviour of Nike products and have an impact on customer loyalty from the perspective of customers in Germany?

Statement 1: Age - How old are you?

Statement 2: From a customer perspective in Germany, "Take a knee" activities have a positive influence on the Nike brand.

Statement 3: From the customer's point of view in Germany, "Take a knee" activities are used by Nike specifically for marketing purposes.

Statement 4: From the customer's point of view in Germany, "Take a knee" activities are used by Nike specifically to increase the sales of product numbers of Nike products.

Statement 5: From the customer's point of view in Germany, "Take a knee" activities are used by the company Nike specifically to increase sales turnovers of its own products. 
Statement 6: Do you agree with the statement that "Take a knee" activities increase customer loyalty to Nike?

\section{Survey findings}

When asked "How old are you?", respondents were asked to state their age. As Graph 1 shows, among the 135 participants' votes, the top three were from the following age groups: [1] With 9 participations the age "33", [2] with 8 participations the age " 35 " and [3] with 7 participations the age " 27 ". Taillights with only one vote each were the age groups: 13, 18, 38, 46, 53, 60 and 66.

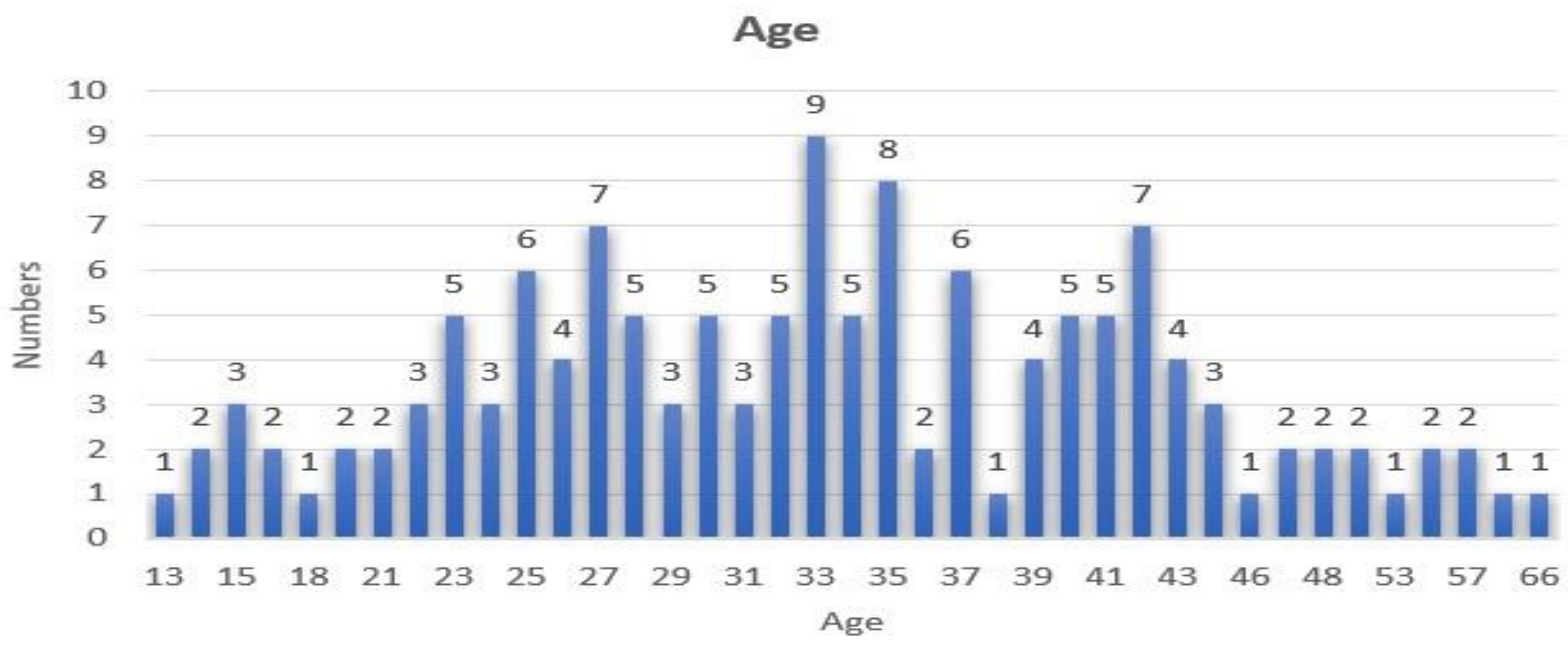

Source: Own representation

Graph 1. Distribution of the age of the survey participants

The following statements can be seen in Graph 2:

In the statement "From a customer perspective in Germany, "Take a knee" activities have a positive impact on the Nike brand" there were four possible answers: [1] True, [2] More likely to be true, [3] More likely not to be true and [4] Not likely to be true. As the graph on the left shows, $17.04 \%$ of respondents chose the answer "Agree", $40.74 \%$ of respondents chose the answer "Agree rather", $28.89 \%$ of respondents chose the answer "Agree rather not" and $13.33 \%$ of respondents chose the answer "Do not agree".

With the statement "From the customer's point of view in Germany, "Take a knee" activities are used by Nike specifically for marketing purposes" there were four possible answers: [1] True, [2] More likely to be true, [3] More likely not to be true and [4] Not likely to be true. As the graph on the left shows, $30.37 \%$ of respondents chose the answer "Agree", $44.44 \%$ of respondents chose the answer "Agree rather", $17.78 \%$ of respondents chose the answer "Agree rather not" and $7.41 \%$ of respondents chose the answer "Do not agree".

With the statement "From the customer's point of view in Germany, "Take a knee" activities are used by the company Nike specifically to increase the sales of product numbers of Nike products" there were four possible answers: [1] True, [2] More likely to be true, [3] More likely not to be true and [4] Not likely to be true. As the graph on the left shows, $28.89 \%$ of respondents chose the answer "Agree", $42.22 \%$ of respondents chose the answer "Agree rather", $22.96 \%$ of respondents chose the answer "Agree rather not" and $5.93 \%$ of respondents chose the answer "Do not agree".

With the statement "From the customer's point of view in Germany, "Take a knee" activities are used by the company Nike specifically to increase sales turnovers of its own products" there were four possible answers: [1] True, [2] More likely to be true, [3] More likely not to be true and [4] Not likely to be true. As the graph on the left shows, $30.37 \%$ of respondents chose the answer "Agree", $41.48 \%$ of respondents chose the answer "Agree rather", $20.74 \%$ of respondents chose the answer "Agree rather not" and $7.41 \%$ of respondents chose the answer "Do not agree". 
From a customer perspective in Germany, "Take a knee" activities have a positive impact on the Nike brand.

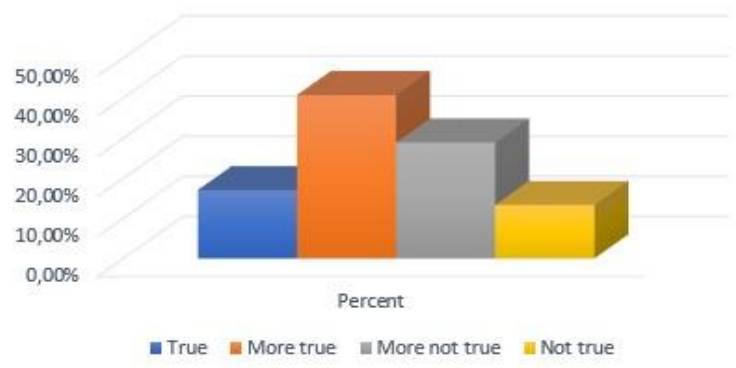

From a customer perspective in Germany, "Take a knee" activities are specifically used by Nike to increase sales numbers of Nike products.

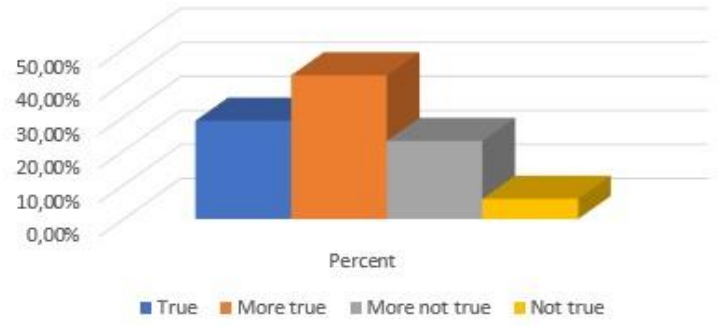

From a customer perspective in Germany, "Take a knee"
activities are used by Nike specifically for marketing purposes.

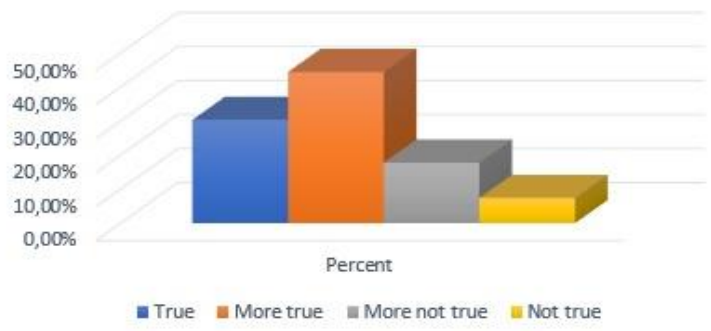

From a customer perspective in Germany, "Take a knee" activities are specifically used by Nike to increase sales revenues of Nike products.

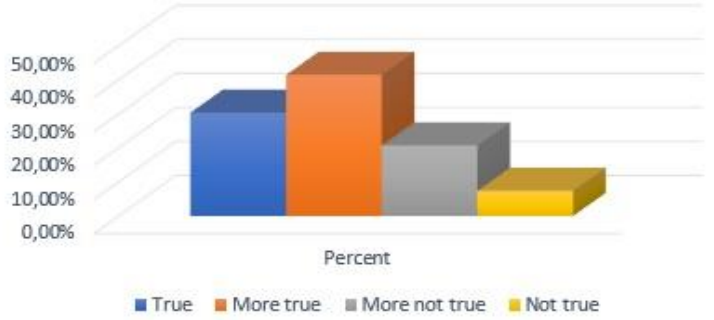

Source: Own representation

Graph 2. Answers to questions 2-5 by the test persons

In response to the question "Do you agree with the statement that "Take a knee" activities increase customer loyalty?" there were two possible answers: [1] Yes and [2] No. As Graph 3 shows, 66.67\% of the respondents chose "Yes" and 33.33\% "No".

\section{Do you agree with the statement that "Take a knee" activities increase customer loyalty to Nike?}

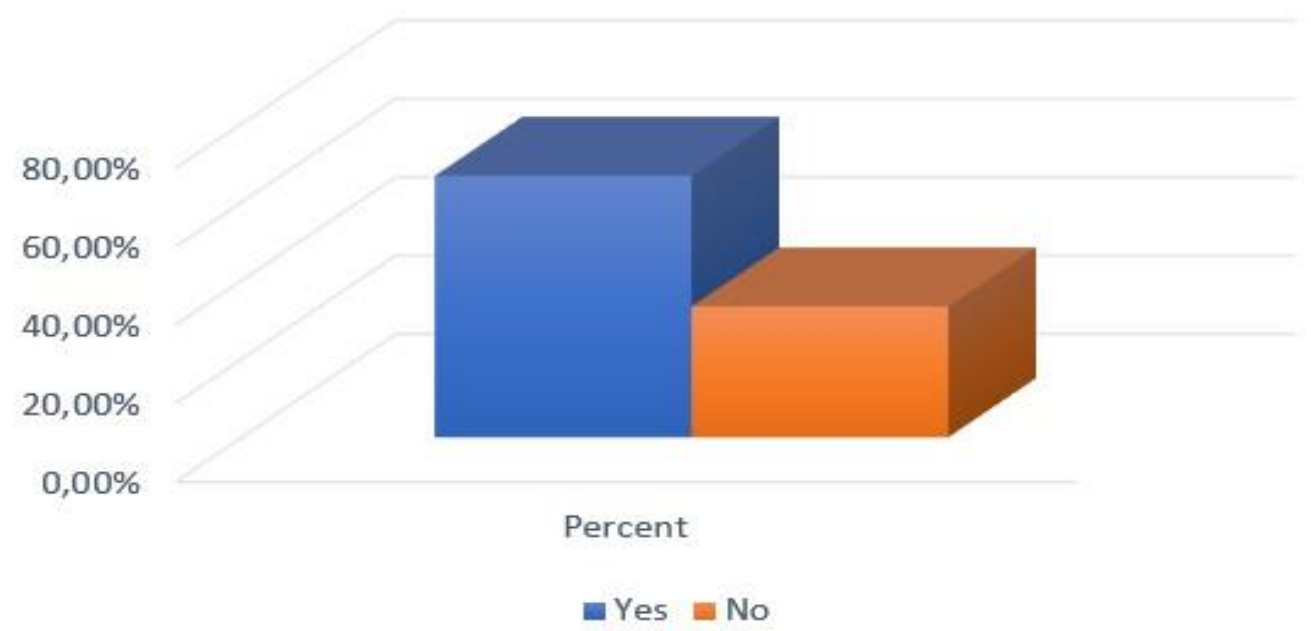

Graph 3. "Take a knee" activities ensure higher customer loyalty to the Nike

Source: Own presentation

\section{Results}

Within the framework of inductive statistics, the statistical software "R" was used to disprove or prove hypotheses with statistical tests. These statistical tests were performed with a significance level of $\alpha=0.05$. For the data preparation we have downloaded the data from www.surveymonkey.de and coded the values of the Likert Scale numerically (e.g. "applies" value 1 and "does not apply" value 4). The values of the questions with answer options "yes" and "no" were binary coded. In our research, we used different statistical tests and selected them according to the respective scale level. 


\section{Statement 1:}

From a customer perspective in Germany, "Take a knee" activities ensure greater customer loyalty to Nike.

The test persons answered the questions independently of each other. Therefore, the answers to the questions can be modeled as "Bernoulli" distributed random variables. The probability that a potential customer of the sports equipment manufacturer Nike will answer this question positively is called p_pos.

Hypothesis: $\mathrm{H}_{0}$ : $\mathrm{p} \_$pos $\leq 0,5$

The probability that a randomly selected respondent will respond positively to the question about higher customer loyalty is $\leq 0.5$ (less than $50 \%$ of participants).

Alternative hypothesis: $\mathrm{H}_{1}$ : p_pos $>0,5$

The probability that a randomly selected respondent will respond positively to the question about higher customer loyalty is $>0.5$ (more than $50 \%$ of participants).

To answer the hypothesis, an (exact) binomial test was performed. The test variable is the number of positive responses and, under the hypothesis, binomially distributed (with $\mathrm{p}=\mathrm{p} \_$pos and $\mathrm{n}=135$ ).

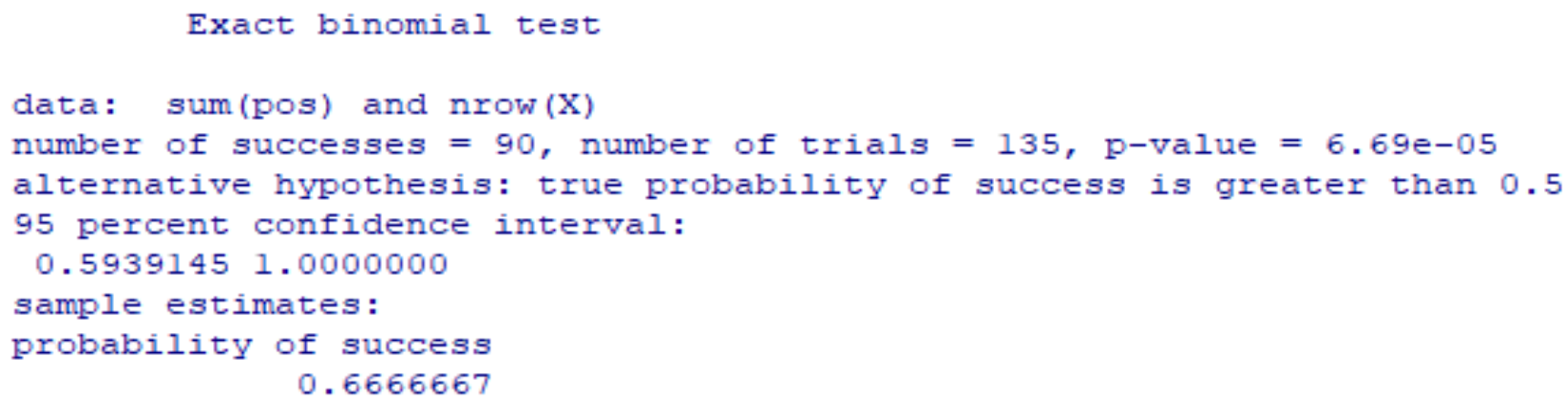

Result: The hypothesis was statistically refuted, since the p-value $=0.0000669<0.05$.

"Take a knee" activities ensure higher customer loyalty from the perspective of potential customers of the sports goods manufacturer Nike.

\section{Statement 2:}

From a customer perspective in Germany, "Take a knee" activities have a positive impact on the Nike brand.

What we want to investigate is: To what extent do "Take a knee" activities have a positive influence on the Nike brand from the perspective of potential customers of the sports goods manufacturer Nike?

Procedure: For each of the 135 potential customers of the sporting goods manufacturer Nike, we received a statement regarding the positive influence on the brand. We know which potential customers have come to the conclusion that "Take a knee" activities have a positive impact on the Nike brand and which have not. According to this assessment, we can "dichotomize" the potential customers.

Now we test whether there is a significant difference in the answer to the question (about the positive influence on the brand).

Background: 135 potential customers answered "yes" or "no" to the question of whether "Take a knee" activities have a positive impact on the Nike brand. So we have two groups, the "yes" and the "no" answerers. We can now compare whether both groups would have answered the question about the positive influence more or less equally. We would like to see that the "yes-men" also plead for a positive influence.

What we have now tested is the question of the difference between the two groups.

Since the Wilcoxon rank sum test is a nonparametric test, no formulas can be used as a hypothesis. The test checks whether the two same groups come from the population.

Hypothesis: Both groups are from the same population. This means that the two groups formed would on average answer the question in a similar way.

Alternative hypothesis: Both groups do not come from the same population. 
In order to answer the hypothesis, a Wilcoxon rank sum test was chosen because an ordinal scale level (Likert scale) with ranking is present.

Wilcoxon rank sum test with continuity correction

data: X[pos, "POS_EINFLUSS_AUF_MARKE"] and X[neg, "POS_EINFLUSS_AUF_MARKE"]

$\mathrm{W}=3218.5, \mathrm{p}$-value $=4.454 \overline{\mathrm{e}}-09$

alternative hypothesis: true location shift is not equal to 0

Result: The p-value is $<0.05$. The test shows that the hypothesis can be rejected.

"Take a knee" activities have a positive impact on the Nike brand from the perspective of potential customers who voted for positive customer retention under statement 1.

Statement 3:

From the customer's point of view in Germany, "Take a knee" activities are used by Nike specifically for marketing purposes.

What we want to investigate is: To what extent are "Take a knee" activities used by Nike for marketing purposes from the perspective of potential customers?

Procedure: For each of the 135 potential customers of the sporting goods manufacturer Nike, we received a statement regarding the targeted use for marketing purposes. We know which potential customers have come to the conclusion that "Take a knee" activities were used specifically for marketing purposes and which not. According to this assessment, we can "dichotomize" the potential customers.

Now we are testing whether there is a significant difference in the answer to the question (after a targeted use for marketing purposes).

Background: 135 potential customers answered "yes" or "no" to the question of whether "Take a knee" activities are used specifically for marketing purposes. So we have two groups, the "yes" and the "no" answerers. We can now compare whether both groups would have answered the question of targeted use more or less equally. We would like to see that the "yes-men" also plead for targeted use.

What we have now tested is the question of the difference between the two groups.

Since the Wilcoxon rank sum test is a nonparametric test, no formulas can be used as a hypothesis. The test checks whether the two same groups come from the population.

Hypothesis: Both groups are from the same population. This means that the two groups formed would on average answer the question in a similar way.

Alternative hypothesis: Both groups do not come from the same population.

In order to answer the hypothesis, a Wilcoxon rank sum test was chosen because an ordinal scale level (Likert scale) with ranking is present.

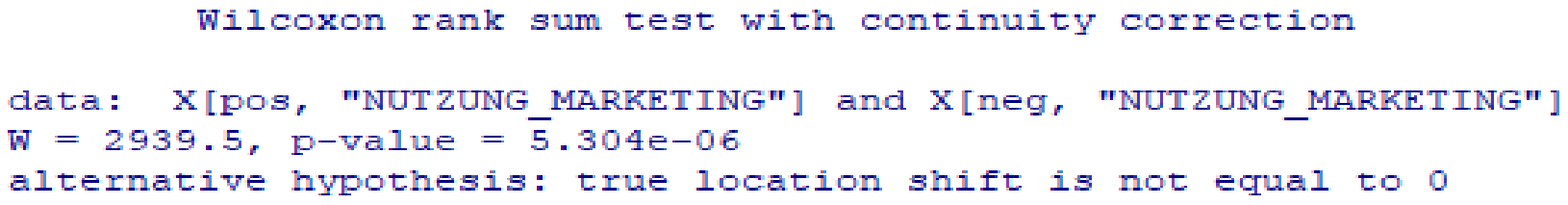

Result: The p-value is $<0.05$. The test shows that the hypothesis can be rejected.

"Take a knee" - activities are used by Nike specifically for marketing purposes from the perspective of potential customers who voted for positive customer retention under statement 1.

$\underline{\text { Statement 4: }}$

From the customer's point of view in Germany, "Take a knee" activities are used by Nike specifically to increase the sales of product numbers of Nike products. 
What we want to investigate is: To what extent are "Take a knee" activities used by Nike specifically to increase the sales of Nike product numbers from the perspective of potential customers?

Procedure: For each of the 135 potential customers of the sports goods manufacturer Nike, we received a statement regarding the targeted sales increase of Nike products. We know which potential customers have come to the conclusion that "Take a knee" activities were used specifically to increase sales and which not. According to this assessment, we can "dichotomize" the potential customers.

Now we are testing whether there is a significant difference in the answer to the question (after a targeted increase in sales of Nike products).

Background: 135 potential customers answered "yes" or "no" to the question of whether "Take a knee" activities provide a targeted increase in sales of Nike products. So we have two groups, the "yes" and the "no" answerers. We can now compare whether both groups would have answered the question of the targeted sales increase more or less equally. We would like to see that the "yes-men" also plead for a targeted increase in sales.

What we have now tested is the question of the difference between the two groups.

Since the Wilcoxon rank sum test is a nonparametric test, no formulas can be used as a hypothesis. The test checks whether the two same groups come from the population.

Hypothesis: Both groups are from the same population. This means that the two groups formed would on average answer the question in a similar way.

Alternative hypothesis: Both groups do not come from the same population.

In order to answer the hypothesis, a Wilcoxon rank sum test was chosen because an ordinal scale level (Likert scale) with ranking is present.

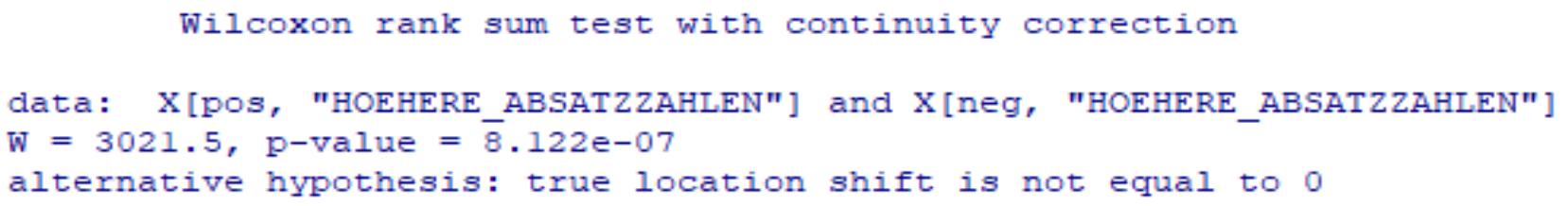

Result: The p-value is $<0.05$. The test shows that the hypothesis can be rejected.

"Take a knee" activities are used by Nike to increase the sales of Nike product numbers from the perspective of potential customers who have voted for positive customer loyalty under statement 1.

\section{Statement 5:}

From the customer's point of view in Germany, "Take a knee" activities are used by the company Nike specifically to increase sales turnovers of its own products.

What we want to investigate is: To what extent are "Take a knee" activities used by Nike specifically to increase sales turnovers of Nike products from the perspective of potential customers?

Procedure: For each of the 135 potential customers of the sports goods manufacturer Nike, we received a statement regarding the targeted sales increase of Nike products. We know which potential customers have come to the conclusion that "Take a knee" activities have been used specifically to increase sales and which have not. According to this assessment, we can "dichotomize" the potential customers.

Now we are testing whether there is a significant difference in the answer to the question (after a targeted increase in sales of Nike products).

Background: 135 potential customers answered "yes" or "no" to the question of whether "Take a knee" activities provide a targeted increase in sales of Nike products. So we have two groups, the "yes" and the "no" answerers. We can now compare whether both groups would have answered the question of the targeted sales increase more or less equally. We would like to see that the "yes-men" also plead for a targeted increase in sales.

What we have now tested is the question of the difference between the two groups. 
Since the Wilcoxon rank sum test is a nonparametric test, no formulas can be used as a hypothesis. The test checks whether the two same groups come from the population.

Hypothesis: Both groups are from the same population. This means that the two groups formed would on average answer the question in a similar way.

Alternative hypothesis: Both groups do not come from the same population.

In order to answer the hypothesis, a Wilcoxon rank sum test was chosen because an ordinal scale level (Likert scale) with ranking is present.

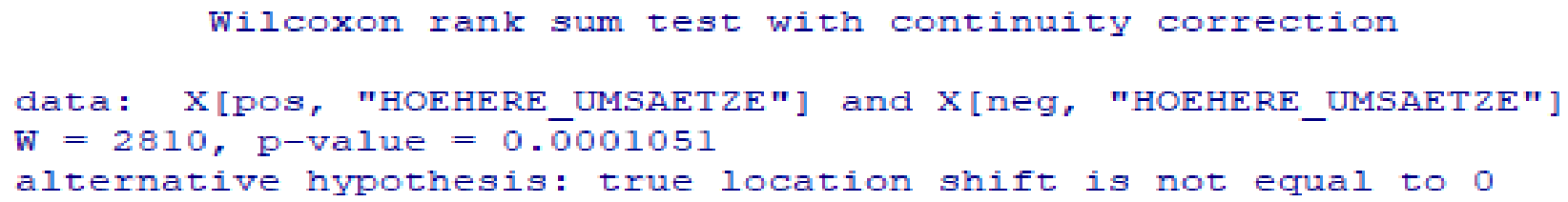

Result: The p-value is $<0.05$. The test shows that the hypothesis can be rejected.

"Take a knee" activities are used by Nike to increase sales turnovers of Nike products from the perspective of potential customers who have voted for positive customer retention under statement 1.

$\underline{\text { Statement 6: }}$

The age of potential customers is not important for customer retention.

The test persons answered the question about age independently of each other.

We refer to the average age of potential customers who have responded positively to the question about higher customer loyalty through "Take a knee" activities as $\mu$ pos. Similarly, we define the average age of potential customers who answered in the negative as $\mu \_$neg.

We test whether the potential customers who have answered positively and those who have answered negatively are on average the same age.

Hypothesis: $H_{0}: \mu \_$neg $=\mu \_$pos

Alternative hypothesis: $\mathrm{H}_{1}: \mu \_$neg $\neq \mu \_$pos

To answer the hypothesis, a (two-sided) t-test was performed. The test variable is the standardized difference of the mean values. Under the hypothesis, the test variable is "student-t-t-distributed".

We do not assume that the standard deviations of the two groups correspond. Therefore, we use the Welch approximation of the degrees of freedom.

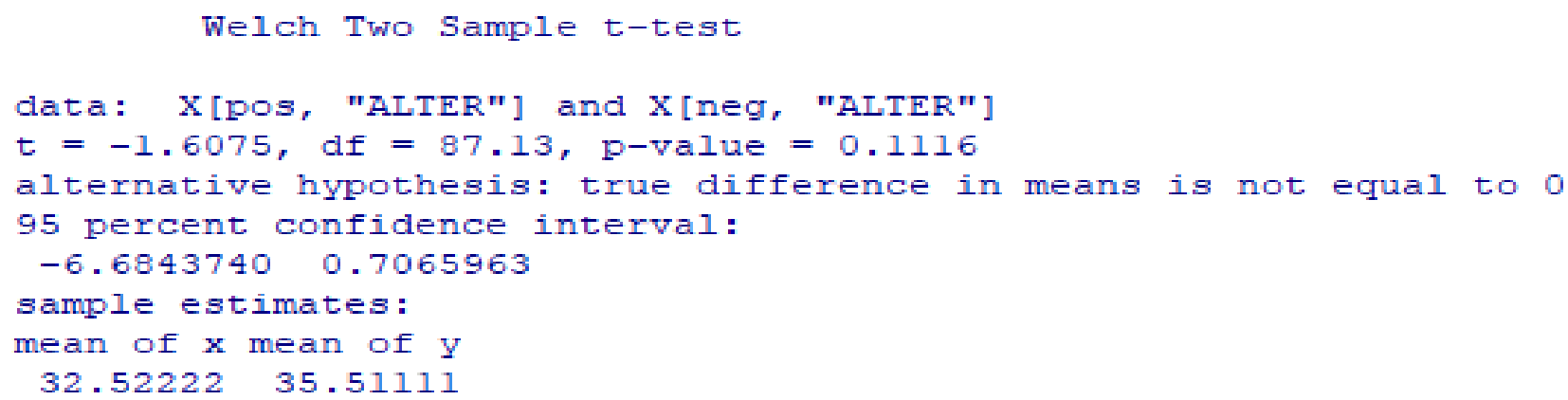

Result: The hypothesis was statistically proven since the $\mathrm{p}$-value $=0.1116$ and thus $>0.05$.

Age has no significant influence on the answer to the question. This is shown in Graph 4. The age distribution of the test persons in the two groups that voted for a positive or negative influence on customer loyalty is similar. 


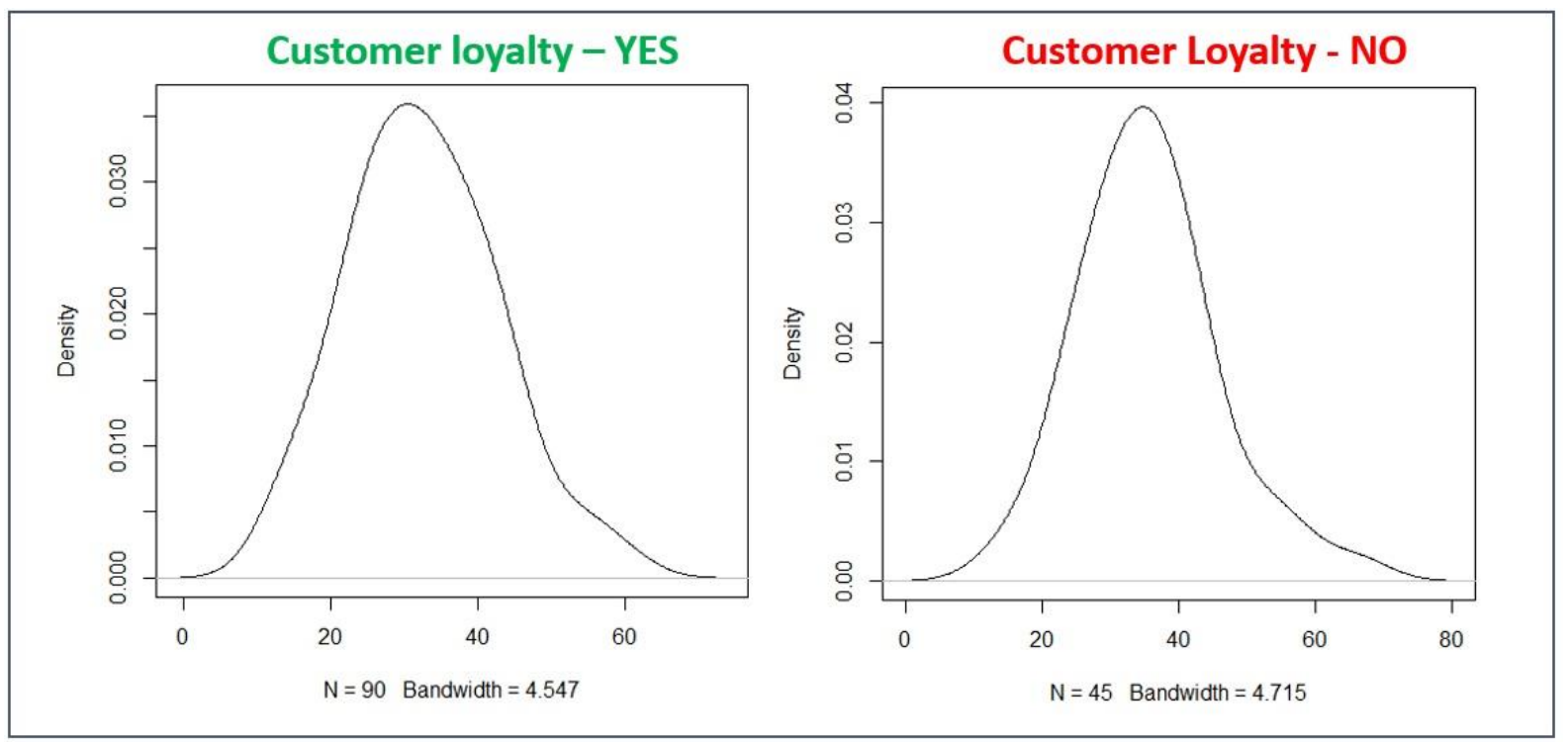

Source: Own presentation

Graph 4. Influence of age on customer loyalty

\section{Conclusions}

The sporting goods market includes all companies that develop, manufacture and trade in sporting goods. The task of sporting goods manufacturers is to produce goods and make them available for sale to consumers. The term marketing describes the consistent orientation of the entire company towards the needs of the market. Brand messages can be conveyed to the desired target group through targeted campaigns (Gabler, 2016). In guerrilla marketing, characteristics of surprise and innovation must be an integral part of the measures. An important prerequisite for the impact of guerrilla marketing is the correspondence between corporate image and the message for the target group (Nufer \& Bender, 2008). The team of Hertha BSC is equipped by Nike and was the first mover with their "Take a knee" action. One can, therefore, speak of a given capacity for innovation. Therefore, it cannot be ruled out that this solidarity with the US athletes might turn out to be a PR exercise. Football (aka soccer) is a special phenomenon. In Germany, it seems to dominate other sports. This refers above all to the media dominance and financial superiority over other sports (Heckemeyer \& Schmidt, 2019). One can assume a big image gain for Hertha BSC and also for the company Nike in Europe.

When you look at the results of our study, it was proven that "Take a knee" activities are specifically used for marketing purposes from the perspective of potential Nike customers and have a positive effect on the brand. In addition, they have an influence on higher customer loyalty, the targeted increase in sales figures and turnover.

In fact, according to an external estimate, immediately after the Kaepernick campaign in 2018, Nike recorded a $31 \%$ increase in online sales compared to the previous year (Martinez, 2018). This means that Nike won as a global brand one way or another. The campaign has triggered an international media response. For every shoe that Trump followers burn, many more are sold in addition. Attitude is apparently rewarded. But there are two sides to the coin. Although Colin Kaepernick had a contract for Nike equipment since 2011, he was only actively involved in their marketing activities two years later (Pitzke, 2018).

For many years, the US-American Nike Group has been the world's largest sporting goods manufacturer. The "Take a knee" activities and the Nike campaign can be considered a commercial success. Graph 5 below shows Nike's worldwide sales in the financial years 2002/2003 to 2018/2018, and for the financial year 2018/2019, Nike's worldwide sales were approximately USD 36,34 billion (www.statista.de). This includes the time of the Kaepernick campaign. 


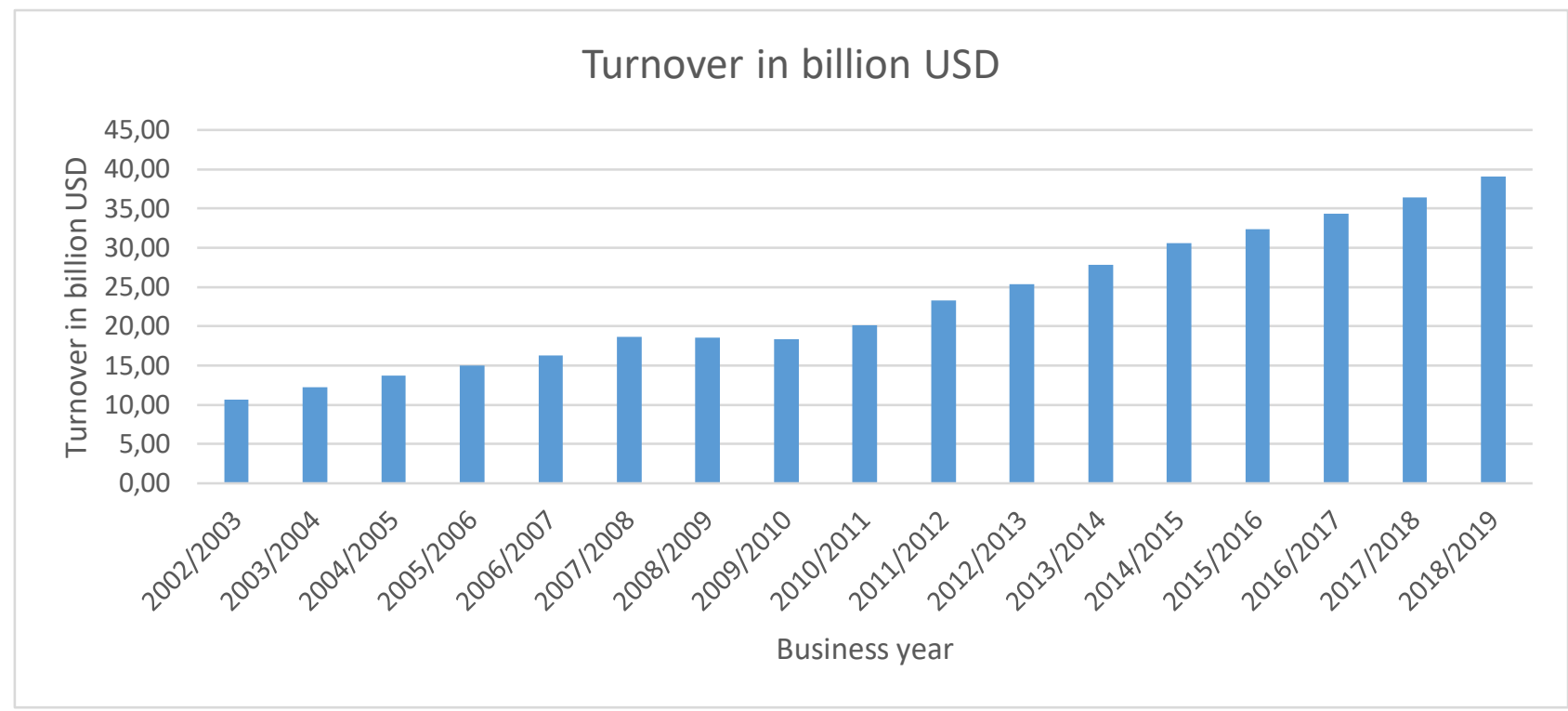

Graph 5. Nike's worldwide sales in the financial years 2002/2003 to 2018/2019 based on www.statista.de

Source: Own presentation

Nike has also been in the spotlight for years in terms of Corporate Social Responsibility (CSR). American companies should decide on full disclosure of social responsibility practices. Social responsibility should become an absolute priority in purchasing decisions, among other things. Research shows that moral operations are also profitable (DeTienne \& Lewis, 2005). As part of this, "Take a knee" activities can provide social purchasing decisions for Nike products.

Research indicates that Colin Kaepernick has assets of USD 20 million (Becker, 2018). Colin Kaepernick's last contract with the San Francisco 49ers was for USD 126 million. From these, he received 39 million USD. In February 2019, the NFL and Kaepernick reached an out-of-court settlement. Colin Kaepernick gets between 60 and 80 million USD from the NFL. The out-of-court settlement should exclude damaging publications of details during legal proceedings. The payment is an admission of debt without having to admit debt (Schmieder, 2019).

With their study, Kane et al. created a framework based on ethical theories to determine whether Kaepernick's protest can be considered right or wrong. A definitive answer cannot be given because an assessment is still based on the individual perception of the assessors (Kane et al, 2017). However, it does not violate the rules, it is neither unconstitutional nor unsportsmanlike. It is a protest against the country itself (Thiel et al., 2016). Political protest and sport is not a new phenomenon. Colin Kaepernick found a strong and controversial form of political action. Kaepernick did this to draw more attention to police violence against blacks in the United States. This situation had a major impact on the media and led to a renewed discussion about Americanism, protest and race (Rorke \& Copeland, 2017). His play clothes from the first protest were exhibited at the Smithsonian National Museum of African American History and Culture. Colin Kaepernick has become a symbol of the American civil rights movement. He has now donated more than one million USD to charitable organizations (Schmieder, 2019).

\section{Limitations and Directions for Further Research}

Is Colin Kaepernick a leader? Adaptive leadership mobilizes people to address difficult social problems and initiate change (Heifetz et al., 2009). If you orientate yourself on it, Kaepernick is a leader. He showed with the chosen method of protest that leadership is not simply a position to be taken. Kaepernick showed in the tradition of adaptive leadership that leadership is a practice (Martin, 2018). Several media in the USA made the claim that Kaepernick ruined the unity of the team at the height of his career. Furthermore, his actions would harm the team. Reporters and experts wondered whether it was wise for them to put themselves in the firing line in public like this (Coombs et.al., 2019). The topic of leadership could be examined in the context of further empirical analyses following on from our study.

The survey aimed to determine whether Nike was using these activities for economic advantage, which was proven. However, the survey does not rule out the possibility that, in addition to the economic aspects, Nike 
actually acted in this way out of a sense of values. This was not considered in the questions of this study and creates opportunities for further research that focuses more specifically on morality and values.

\section{Acknowledgement}

The authors would like to thank the two anonymous reviewers for reading, reflecting, evaluating and constructively commenting, which contributed significantly to the finalization of this study. Furthermore, we would like to thank 'ARMG Publishing' and the scientists involved for the possibility of publication and the appreciative cooperation.

\section{References}

1. Agosto, V., Wolgemuth, J., White, A., Grosland, T., \& Feldman, A. (2019). The Emotional Labor of "Taking a Knee". The International Journal of Critical Media Literacy, 1(1), 102-117. DOI:https://doi.org/10.1163/25900110-00101009.

2. Becker, J. (2018). Warum Nike jetzt mit NFLer Colin Kaepernick wirbt [Why Nike now advertises with NFLer Colin Kaepernick]. Available at: https://www.der-zukunftsfonds.de/zaster/colin-kaepernick [Accessed February 2020].

3. Coombs, D. S., Lambert, C. A., Cassilo, D., \& Humphries, Z. (2019). Flag on the play: Colin Kaepernick and the protest paradigm. Howard Journal of Communications, (Latest Articles), 1-20. DOI:https://doi.org/10.1080/10646175.2019.1567408.

4. DeTienne, K. B., \& Lewis, L. W. (2005). The pragmatic and ethical barriers to corporate social responsibility disclosure: The Nike case. Journal of Business Ethics, 60(4), 359-376. DOI:https://doi.org/10.1007/s10551-005-0869-x.

5. Gabler, Wirtschaftslexikon (2016). Marketing. Available at: https://wirtschaftslexikon.gabler.de/definition/marketing-39435/version-262843 [Accessed February 2020].

6. Heckemeyer, K., \& Schmidt, H. (2019). Fußball, Politik und Gesellschaft [Football (aka Soccer), Politics and Society]. FuG-Zeitschrift für Fußball und Gesellschaft, 1(1). DOI: https://doi.org/10.3224/fug.v1i1.01.

7. Heifetz, R., Grashow, A., \& Linsky, M. (2009). Leadership in a (permanent) crisis. Harvard business review, 87(7/8), 62-69. Available at: https://www.counties.org/sites/main/files/file-attachments/tab_11__perspectives.pdf.

8. Hibbitts, C. B. (2018). To Kneel or Not to Kneel: A Balancing Act of First Amendment Rights. Available at: https://uknowledge.uky.edu/cgi/viewcontent.cgi?filename=0\&article=1129\&context=law_kljblog\&type=addit ional.

9. Kane, D., Tiell, B., \& Intercollegiate, A. (2017). Application of normative ethics to explain Colin Kaepernick's silent protest in the NFL. Sport Journal, 21, 1-11. Available at: http://thesportjournal.org/article/application-ofnormative-ethics-to-explain-colin-kaepernicks-silent-protest-in-the-nfl/.

10.Lindholm, J. (2017). From Carlos to Kaepernick and beyond: athletes' right to freedom of expression. The International Sports Law Journal, 17, 1-3. DOI: https://doi.org/10.1007/s40318-017-0117-4.

11.Martin, L. L. (2018). The politics of sports and protest: Colin Kaepernick and the practice of leadership. American Studies Journal, 64, 1-12. DOI: https://doi.org/10.18422/64-06.

12.Martin, S., \& McHendry Jr, G. F. (2016). Kaepernick's Stand: Patriotism, Protest, and Professional Sports. Journal of Contemporary Rhetoric, 6, 88-98. Available at: http://contemporaryrhetoric.com/wpcontent/uploads/2017/01/Martin_McHendry13_4.pdf.

13.Martinez, G. (2018). Despite "Outrage”, Nike Sales Increased 31\% After Kaepernick Ad. Available at: https://kaepernick7.com/blogs/news/despite-outrage-nike-sales-increased-31-after-kaepernick-ad [Accessed February 2020].

14.Nufer, G., \& Bender, M. (2008). Guerilla Marketing (No. 2008-05). Reutlinger Diskussionsbeiträge zu Marketing \& Management. DOI: http://hdl.handle.net/10419/57387.

15.Pitzke, M. (2018). Nike-Werbung mit Footballer Kaepernick, Kommerz und Kontroverse, Spiegel Online. https://www.spiegel.de/wirtschaft/unternehmen/colin-kaepernick-nike-setzt-mit-werbung-zeichen-undprofitiert-davon-a-1226741.html [Accessed February 2020].

16.Rorke, T., \& Copeland, A. (2017). Athletic disobedience: providing a context for analysis of Colin Kaepernick's protest. FairPlay, Revista de Filosofia, Ética y Derecho del Deporte, (10), 83-107. Available at: https://www.raco.cat/index.php/FairPlay/article/view/327610.

17.Schmieder, J. (2019). Ein Scheck zur Versöhnung [A cheque for reconciliation]. Available at: https://www.sueddeutsche.de/sport/kaepernick-nfl-football-einigung-1.4333760 [Accessed February 2020]. 
18.Sohn, M. (2017). German Soccer Team Kneels in Solidarity With N.F.L. Players' Protests. The New York Times. Available at: https://www.nytimes.com/2017/10/14/sports/soccer/german-soccer-team-kneels-insolidarity-with-nfl-players-protests.html [Accessed February 2020].

19.Tagesanzeiger (2020). Hertha-Spieler wird rassistisch beleidigt und weint auf dem Feld [Hertha player gets racially insulted and cries on the pitch]. Available at:

https://www.tagesanzeiger.ch/sport/fussball/herthaspieler-wird-rassistisch-beleidigt-und-weint-auf-demfeld/story/11779097 [Accessed February 2020].

20.The New York Times (2017). German Soccer Team Kneels in Solidarity With N.F.L. Players' Protests. Available at: https://www.nytimes.com/2017/10/14/sports/soccer/german-soccer-team-kneels-in-solidaritywith-nfl-players-protests.html [Accessed February 2020].

21.Thiel A., Villanova, A., Toms, M., Thing, L.F. \& Dolan, P. (2016). Can sport be 'un-political'? European Journal for Sport and Society, 13(4), 253-255, DOI: 10.1080/16138171.2016.1253322.

22.Umsatz von Nike weltweit in den Geschäftsjahren 2002/2003 bis 2018/2019. [Nike's worldwide turnover in the financial years 2002/2003 to 2018/2019]. Available at:

https://de.statista.com/statistik/daten/studie/158744/umfrage/umsatzentwicklung-von-nike-weltweit-seit-2004/.

23.Zannell, L. (2018). The white open. Leisure Studies, 37(6), 645-647.

DOI: https://doi.org/10.1080/02614367.2018.1535615. 